\title{
The relationship between out-of-hours admission to icu and patient outcome
}

\author{
A Gupta*, P Morgan \\ From ESICM LIVES 2015 \\ Berlin, Germany. 3-7 October 2015
}

\section{Introduction}

At present, there is a paucity of information delineating the relationship between patient outcome and after-hours admissions to ICU. Studies have demonstrated either higher mortality rates or have shown no increased risk with off-hours ICU admissions, even when confounding factors are accounted for [1-3].

\section{Objectives}

To evaluate the relationship between the mortality rates of patients admitted to ICU and their time of their admission.

\section{Methods}

Retrospective cohort study $(\mathrm{n}=9092)$ of patients aged between 17-98 years, admitted to SASH ICU between Dec
1992-Dec 2014 were categorised into out-of-hours (17:0008:00) or in-hours (08:00-17:00) admission. Mortality rates in each group were calculated. Elective surgical admissions were excluded.

\section{Statistical Analysis:}

Categorical data, analysed using Fisher's, Chi-Square and $2 \times 2$ contingency tables.

\section{Results}

Of the 9092 patients, 5765 were admitted out-of-hours and 3327 were admitted in-hours.

There was a statistically significant difference $(\mathrm{p}=$ $0.0013)$ in mortality between the out-of-hours $(28.2 \%)$ and in-hours group (31.9\%).

The data shows convincing evidence that patients have a worse outcome when admitted during normal working

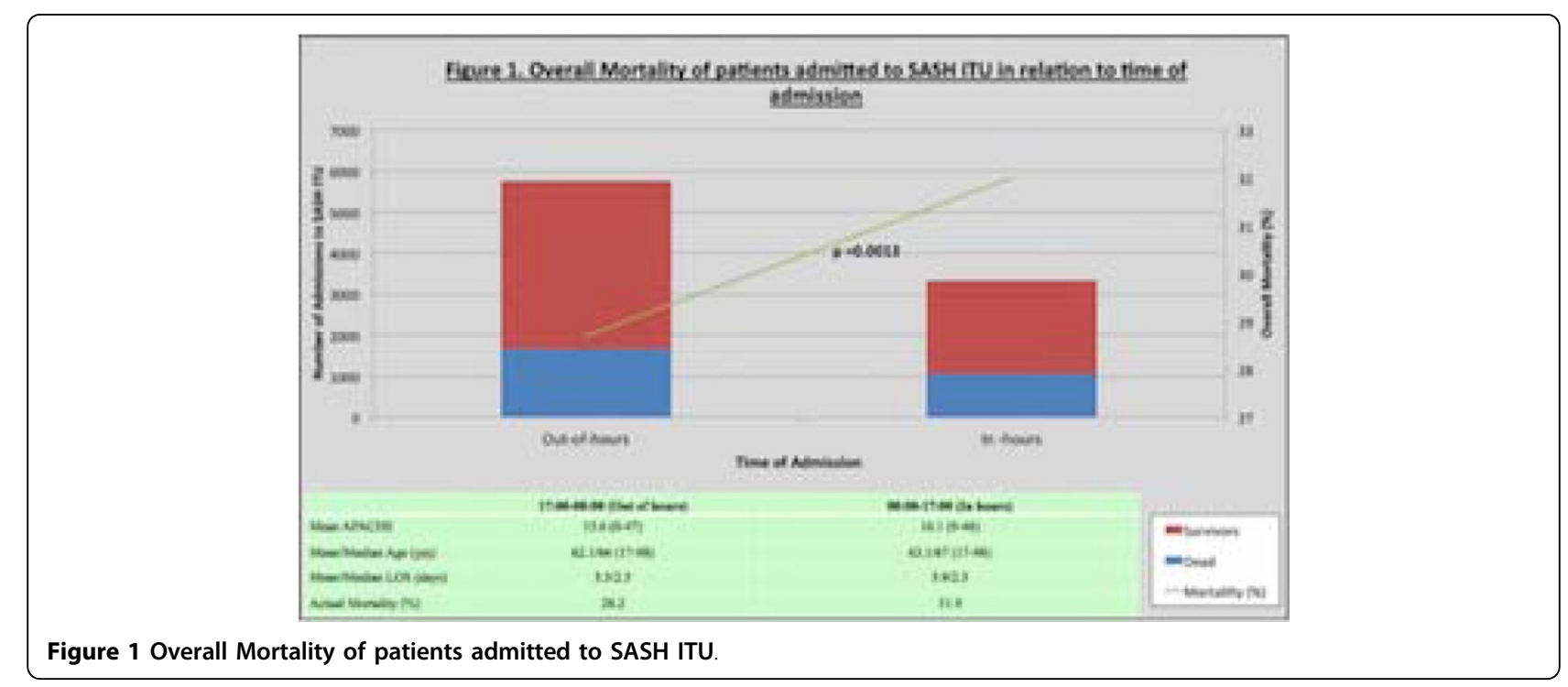

Surrey and Sussex Hospitals Trust, Intensive Care, Redhill, United Kingdom

(c) 2015 Gupta et al.; This is an Open Access article distributed under the terms of the Creative Commons Attribution License (http:// creativecommons.org/licenses/by/4.0), which permits unrestricted use, distribution, and reproduction in any medium, provided the original work is properly cited. 
hours even though in-hours, there is increased access to hospital resources (doctors, nurses, investigations and specialist services) compared to out-of-hours. Interestingly, when extrapolated further, survival worsens particularly in the first few hours of the working day. This corresponds to the time of day where ICU has the fewest number of admissions (Figure 2).

We can only speculate as to the underlying cause of this result and further work will need to be completed in order to understand the causative factors. This will include assessing staff availability to review patients or action management plans and delayed admissions from overnight.

\section{Conclusions}

There is a survival benefit for patients admitted out-ofhours compared to those admitted during in-hours. Further studies need to done in order to ascertain the factors that contribute to this finding.

Published: 1 October 2015

\section{References}

1. Uusaro A, Kari A, Ruokonen E: The effects of ICU admission and discharge times on mortality in Finland. Intensive Care Med 2003, 29(12):2144-8.

2. Ensminger SA, Morales IJ, Peters SG, et al: The hospital mortality of patients admitted to the ICU on weekends. Chest 2004, 126(4):1292-8, 324. K.B. Laupland et al..

3. Arabi Y, Alshimemeri A, Taher S: Weekend and weeknight admissions have the same outcome of weekday admissions to an intensive care unit with onsite intensivist coverage. Crit Care Med 2006, 34(3):605-11.

doi:10.1186/2197-425X-3-S1-A961

Cite this article as: Gupta and Morgan: The relationship between out-ofhours admission to icu and patient outcome. Intensive Care Medicine Experimental 2015 3(Suppl 1):A961.

\section{Submit your manuscript to a SpringerOpen ${ }^{\mathcal{O}}$ journal and benefit from:}

- Convenient online submission

- Rigorous peer review

- Immediate publication on acceptance

- Open access: articles freely available online

- High visibility within the field

- Retaining the copyright to your article

Submit your next manuscript at $\gg$ springeropen.com 